\title{
STRATEGI PENERAPAN PARADIGMA BARU DALAM PERAN AUDITOR INTERNAL ORGANISASI PEMERINTAH
}

\author{
Sri Rahayu ${ }^{1 *}$, Yudi $^{2)}$ dan Rahayu ${ }^{3)}$ \\ Program Studi Akuntansi, Universitas Jambi ${ }^{* * 2,3)}$ \\ Jalan Raya Jambi Muara Bulian KM 15, Mendalo Darat, Jambi, Indonesia \\ E-mail: srijambi@gmail.com ${ }^{1 *}$
}

\begin{abstract}
This paper was intended to identify the applied strategies administered by the internal auditors in the governmental institutions in order to run the new paradigm. The quantity and the quality of the government's internal auditors, nowadays, need to be extended. The transformation from the old paradigm to the new one aimed to support the institution's development. Internal auditor is no longer having a role as a watchdog, but it should also play an important role as the consultant and the catalyst like a business partner. The author revealed seven additional work-focuses of internal auditor as the implementation strategies of the new paradigm such as: (1) from hard control to soft control; (2) from control evaluation to self assessment; (3) from control to risk; (4) from detective to preventive; (5) from audit knowledge to business knowledge; (6) from operational audit to strategy audit; and (7) from independent to value. These new roles will potentially be unattainable if the auditors are incompetent, there is no commitment support from the head of the institution, and the awareness level of the auditee is low.
\end{abstract}

Keywords: Soft Control, Bussiness Knowledge, Strategy Audit, Value 


\section{Pendahuluan}

Akuntansi Pemerintah mengalami ketertinggalan dibandingkan akuntansi swasta, hal ini dibuktikan dengan kewajiban organisasi pemerintah untuk menerapkan basis akrual penuh baru dilakukan sejak dikeluarkannya PP No 71 Tahun 2010. Diamond (2002) menyatakan bahwa akuntansi akrual merupakan salah satu komponen reformasi sistem penganggaran pada organisasi pemerintah. Basis akrual memang memiliki kelebihan dan kelemahan. Beberapa kelebihan basis akrual antara lain proses alokasi sumber daya menjadi lebih baik, memperkuat akuntabilitas, meningkatkan transparansi dan memberikan pandangan yang komprehensif tentang dampak pemerintah terhadap ekonomi (Diamond, 2002). Jones and Pendlebury (2010) menyatakan bahwa Basis Akrual memiliki beberapa kelemahan antara lain membutuhkan kompetensi SDM yang lebih tinggi, dukungan sarana dan prasaran yang lebih baik, membutuhkan biaya administrasi dan akuntansi yang lebih mahal dan subjektivitas yang tinggi dapat dibatasi dengan adanya standar akuntansi dan audit (Bastian, 2006).

Pengawasan terhadap pengelolaan keuangan perlu ditingkatkan. Salah satu pihak yang mempunyai tugas dalam melakukan pengawasan dalam tata kelola keuangan organisasi pemerintah adalah auditor internal.

Tata kelola keuangan akan tercapai apabila Pengendalian Internal berjalan efektif. Auditor internal memiliki tugas untuk mengawasi efektivitas pengendalian internal.

Penerapan sistem pengendalian internal pemerintah di Indonesia masih harus terus ditingkatkan agar dapat mengoptimalkan keandalan pelaporan keuangan pemerintah. BPK mengungkapkan dari 9.729 temuan yang memuat 14.997 permasalahan, 49\% diantaranya merupakan permasalahan kelemahan pengendalian internal (BPK, 2017). Walaupun telah terjadi peningkatan Perolehan opini WTPyang diperoleh oleh pemerintah pusat, kementerian dan lembaga serta pemerintah daerah, namun perbaikan terhadap sistem pengendalian intern masih harus terus dilakukan.

Keandalan pelaporan keuangan merupakan salah satu indikasi kualitas laporan keuangan pemerintah. Salah satu indikator untuk mengukur kualitas laporan keuangan pemerintah adalah opini audit yang diberikan oleh Badan Pemeriksa Keuangan (BPK). Selain itu, opini audit juga dapat dijadikan sebagai salah satu indikator akuntabilitas pengelolaan keuangan.

Berdasarkan ikhtisar hasil pemeriksaan BPK, Semester
1 Tahun 2017, terjadi peningkatan opini BPK atas atas LKPP Tahun 2016 yang memperoleh WTP. Padatahun sebelumnya LKPP memperoleh opini Wajar Dengan Pengecualian (WDP). Pada tingkat kementerian dan lembaga, hasil opini LKKL untuk periode 2013-2015, Perolehan opini WTP cenderung mengalami penurunan dari $75 \%$ pada tahun 2013 menjadi $65 \%$ pada tahun 2015. Namun, pada tahun 2016 kecenderungan tersebut berubah yaitu LKKL yang memperoleh opini WTP mengalami kenaikan yang cukup signifikan menjadi $84 \%$. Kenaikan opini WTP tersebut diiringi dengan penurunan yang signifikan atas opini WDP, yaitu dari 30\% pada tahun 2015 menjadi $9 \%$ pada tahun 2016. Sedangkan opini TMP dalam 5 tahun terakhir cenderung berfluktuasi, tetapi masih di bawah $10 \%$.

Hasil opini terhadap Laporan Keuangan Pemerintah daerah (LKPD) baik provinsi maupun kabupaten/kota juga terus mengalami peningkatan. Dalam 5 tahun terakhir (2012-2016), opini LKPD mengalami perbaikan. Selama periode tersebut, LKPD yang memperoleh opini WTPnaik sebanyak 47 poin persen, yaitu dari 23\% pada LKPD Tahun 2012 menjadi $70 \%$ pada LKPD Tahun 2016. Sementara itu, jumlah LKPD yang memperoleh opini TMP mengalami penurunan sebanyak 11 poin persen dari $15 \%$ pada LKPD Tahun 2012 menjadi 4\% pada LKPD Tahun 2016. Kenaikan opini dari tahun 2015 terjadi pada seluruh tingkat pemda. Pada pemerintah provinsi, opini WTP bertambah dari 29 LKPD (85\%) menjadi 31 LKPD $(91 \%)$.

Begitu pula untuk pemerintah kabupaten yang bertambah dari 224 LKPD (54\%) menjadi 272 LKPD (66\%), dan pada pemerintah kota dari 60 LKPD (65\%) menjadi 72 LKPD (78\%). Kenaikan opini dari TW/ TMP/ WDP menjadi WTP pada 84 LKPD dan dari TW/ TMP menjadi WDP pada 15 LKPD dikarenakan pemda telah menindaklanjuti hasil pemeriksaan BPK tahun 2015 dengan melakukan perbaikan atas kelemahan sistem pengendalian intern maupun ketidakpatuhan terhadap ketentuan peraturan perundang-undangan, sehingga akun-akun dalam laporan keuangan telah disajikan dan diungkapkan sesuai dengan SAP.

Pengendalian internal merupakan proses, kebijakan dan prosedur yang dirancang oleh manajemen untuk memastikan pelaporan keuangan yang andal dan pembuatan laporan keuangan sesuai dengan kerangka akuntansi yang berlaku (Tuanakotta, 2014). PP No. 60 Tahun 2008 menyatakan empat tujuan utama dari sistem pengendalian internal organisasi adalah: memberikan keyakinan memadai atas tercapainya tujuan organisasi melalui:

1. kegiatan yang efektif dan efisien,

2. keandalan pelaporan keuangan,

3 pengamanan aset negara,

4.Ketaatan terhadap peraturan

Penerapan sistem pengendalian internal akan dapat mengurangi dan menghindari terjadinya kecurangan dalam pengelolaan keuangan organisasi. 
Peningkatan peran Aparat Pengawas Internal Pemerintah (APIP) dalam hal ini auditor internal diharapkan dapat meningkatkan akuntabilitas kinerja, pengelolaan keuangan dan kualitas laporan keuangan. Selaku auditor internal maka APIP memiliki empat dimensi pekerjaan yaitu evaluasi, diagnosis, memberi informasi dan rekomendasi. (Anto, Sutaryo, \& Payamta, 2016) menyatakan bahwa kualitas auditor independen akan mempengaruhi efektivitas audit internal pemerintah.

Perubahan utama dari peran auditor internal pemerintah yaitu dari watchdog ke konsultan dan katalisator. Sikap auditor berubah dari seperti penjaga atau polisi menjadi mitra bagi klien. Pendekatan yang digunakan lebih bersifat preventif (mencegah masalah). Fokus pekerjaan sebagai watchdog adalah kelemahan/penyimpangan, namun sebagai konsultan dan katalisator lebih fokus pada penyelesaian yang konstruktif (Hery, 2017). Dalam menerapkan peran sebagai konsultan dan katalisator auditor membutuhkan strategi yang tepat.

Pengembangan dari ketiga bentuk peran tersebut telah diungkapkan oleh Pickett (2010) dan Rahayu and Rahayu (2016). Rahayu dan Rahayu (2016) mengungkap tujuh dari sembilan belas konteks perubahan auditor internal yang disampaikan oleh Pickett (2010) yaitu (1) dari hard control menjadi soft control; (2) dari control evaluation menjadi self assessment; (3) dari control menjadi risk; (4) dari detektif menjadi preventif; (5) dari audit knowledge menjadi bussiness knowledge; (6) dari operational audit menjadi strategy audit dan (7) dari independen menjadi value. Artikel ini mencoba mengungkap masing-masing strategi tersebut. Artikel ini merupakan telaah konseptual atas strategi penerapan paradigma baru peran auditor internal pada organisasi pemerintah

\section{Hasil dan Pembahasan}

\subsection{Kondisi Auditor Internal Pemerintah}

Pengawasan terhadap penerapan sistem pengendalian internal pemerintah menjadi salah satu tugas dari Aparatur Pengawasan Internal Pemerintah (APIP). Indonesia menghadapi permasalahan APIP dari sisi kuantitas maupun kualitas APIP. Pada tahun 2014, Auditor internal yang tersebar di pemerintah pusat, daerah, BUMN dan organisasi pemerintah lainnya berjumlah 12.755 atau $(27,94 \%)$ dari total kebutuhan nasional 46.560 sehingga terjadi kekurangan 33.805 auditor. Pemerintah menargetkan pada tahun 2019 diharapkan berjumlah 20.255 auditor atau 43,50\% dari kebutuhan nasional (Inspektorat Provinsi Jawa Tengah, 2016).

Kualitas Auditor internal dapat dilihat salah satunya dari sisi kapabilitasnya. Institute of Internal Auditors (IIA) telah mengembangkan Internal Audit Capability Model (IA-CM). Kapabilitas APIP dapat dinilai dengan menggunakan kriteria ini dengan lima kelompok tingkatan yaitu tingkat 1: Initial, tingkat 2: Infrastructure, tingkat 3: Integrated, tingkat 4: Managed, and tingkat 5: Optimizing. Gambaran tentang kapabilitas auditor internal pemerintah yang tersebar di kementerian/lembaga, pemerintah provinsi dan pemerintah kabupaten/kota dapat dilihat pada Tabel 1.

Tabel 1

Kapabilitas APIP Pemerintah (31 Maret 2016)

\begin{tabular}{|c|c|c|c|c|c|}
\hline \multirow[b]{2}{*}{ Tingkatan } & \multirow[b]{2}{*}{ Keterangan } & \multicolumn{4}{|c|}{ Per 31 Maret 2016} \\
\hline & & $\begin{array}{c}\text { APIP } \\
\text { Nasional }\end{array}$ & $\begin{array}{c}\text { APIP } \\
\text { K/L }\end{array}$ & $\begin{array}{l}\text { APIP } \\
\text { Prov }\end{array}$ & \begin{tabular}{|c|} 
APIP \\
Kab/Kotata
\end{tabular} \\
\hline $\begin{array}{l}\text { Belum di } \\
\text { Asses }\end{array}$ & APIP yang belum dinilai tingkatannya & $16 \%$ & $33 \%$ & $3 \%$ & $14 \%$ \\
\hline $\begin{array}{l}\text { Tingkat 1: } \\
\text { Initial }\end{array}$ & $\begin{array}{c}\text { APIP belum dapat memberikan jaminan atas } \\
\text { proses tata kelola sesuai peraturan dan } \\
\text { mencegah korupsi } \\
\end{array}$ & $60 \%$ & $37 \%$ & $59 \%$ & $64 \%$ \\
\hline $\begin{array}{l}\text { Tingkat } 2: \\
\text { Infrastruktur }\end{array}$ & $\begin{array}{c}\text { APIP mampu memberikan keyakinan yang } \\
\text { memadai proses sesuai dengan peraturan, dan } \\
\text { mampu mendeteksi terjadinya korupsi }\end{array}$ & $23 \%$ & $24 \%$ & $38 \%$ & $22 \%$ \\
\hline $\begin{array}{l}\text { Tingkat 3: } \\
\text { Intergrated }\end{array}$ & $\begin{array}{l}\text { APIP mampu menilai efisiensi, efektivitas, } \\
\text { ekonomis suatu kegiatan dan mampu } \\
\text { memberikan kontribusi pada tata kelola, } \\
\text { manajemen risiko dan pengendalian intern }\end{array}$ & $1 \%$ & $6 \%$ & $0 \%$ & $0 \%$ \\
\hline $\begin{array}{l}\text { Tingkat 4: } \\
\text { Managed }\end{array}$ & $\begin{array}{l}\text { APIP mampu memberikan Assurances secara } \\
\text { keseluruhan atas tata kelola, manajemen risiko } \\
\text { dan pengendalian intern }\end{array}$ & - & - & - & - \\
\hline $\begin{array}{l}\text { Tingkat 5: } \\
\text { Optimizing } \\
\end{array}$ & APIP menjadi agen perubahan & - & - & - & - \\
\hline & Jumlah & 628 & 86 & 34 & 508 \\
\hline
\end{tabular}

Sumber: Inspektorat.Jatengprov, 2016.

Berdasarkan Tabel 1 dapat dilihat tingkat kapabilitas APIP pemerintah masih dominan berada pada tingkat pertama belum mampu menjamin terselenggaranya tata kelola dan belum mampu mendeteksi terjadinya korupsi. Menurut PP No. 60 Tahun 2008 menyatakan perwujudan peran APIP yang efektif sekurang kurangnya harus:

a. memberikan keyakinan yang memadai atas ketaatan, kehematan, efisiensi, dan efektivitas pencapaian tujuan penyelenggaraan tugas dan fungsi Instansi Pemerintah;

b. memberikan peringatan dini dan meningkatkan efektivitas manajemen risiko dalam penyelenggaraan tugas dan fungsi Instansi Pemerintah; dan

c. memelihara dan meningkatkan kualitas tata kelola penyelenggaraan tugas dan fungsi Instansi Pemerintah.

APIP yang berada pada tingkat 3 dalam kategori efektif baru berjumlah 5 (lima) orang.

Salah satu strategi yang dilakukan pemerintah saat ini dengan keterbatasan SDM dan tuntutan profesionalisme yang tinggi melalui penggunaan paradigma baru bagi peran APIP.

\subsection{Wajah Auditor Internal Dulu dan Sekarang}

Pergeseran filosofi internal auditing ditandai dengan perubahan orientasi dan peran profesi internal auditor. Pada abad 21 ini internal auditor lebih berorientasi memberikan kepuasan kepada jajaran manajemen sebagai pelanggan (customer satisfaction) (Rahayu dan Rahayu, 2016). 
Dadang Kurnia, Deputi Kepala BPKP, Bidang Pengawasan Penyelenggaran Keuangan Daerah, menyebutkan perlu dilakukannya transformasi Aparat Pengawas Internal Pemerintah (APIP). Transformasi adalah perubahan rupa (bentuk, sifat, fungsi, dan sebagainya). Transformasi Auditor internal dibutuhkan karena:

- Organisasi tidak dapat menjalankan tugas dan fungsi dengan optimal

- Tantangan tugas baru

- Persaingan yang ketat

- Perkembangan teknologi

- Ekspektasi Stakeholders

Tabel 2

Perbandingan Paradigma Lama dan Baru Auditor Internal

\begin{tabular}{|l|l|l|}
\hline \multicolumn{1}{|c|}{ URAIAN } & \multicolumn{1}{|c|}{ PARADIGMA LAMA } & \multicolumn{1}{c|}{ PARADIGMA BARU } \\
\hline Peran & Watchdog & Konsultan \& Katalis \\
Pendekatan & Detektif (mendeteksi masalah) & Preventif (mencegah masalah) \\
Sikap & Seperti polisi & Sebagai mitra bisnis/customer \\
Ketaatan/kepatuhan & Semua policy/kebijakan & Hanya policy yang relevan \\
Fokus & Kelemahan/penyimpangan & Penyelesaian yang konstruktif \\
$\begin{array}{l}\text { Komunikasi dengan } \\
\text { manajemen }\end{array}$ & Terbatas & Reguler \\
Audit & Financial/compliance audit & $\begin{array}{l}\text { Financial, compliance,operasional } \\
\text { audit } \\
\text { Berkembang luas (dapat berkarir } \\
\text { di bagian/fungsi lain) }\end{array}$ \\
\hline Jenjang karir & Sempit (hanya auditor) & \\
\hline
\end{tabular}

Perubahan peran APIP yang bertugas sebagai auditor internal pemerintah diharapkan dapat meningkatkan kualitas kinerja (Inspektorat.Jatengprov, 2016). Transformasi bertujuan untuk berkembangnya organisasi menuju tingkat yang lebih tinggi (Pramono, 2016).

Perbedaan paradigma lama dengan paradigma baru digambarkan oleh Arief (2008) dalam (Hidayat, 2011) disajikan pada Tabel 2. Internal auditor tidak dapat lagi hanya berperan sebagai watchdog, namun harus dapat berperan sebagai mitra bisnis (Rahayu dan Rahayu, 2016). Peran sebagai Watchdog dijalankan auditor dengan memantau kegiatan operasional serta memberikan peringatan jika terjadi penyelewengan. Kegiatan yang dilakukan berupa observasi, perhitungan dan pengecekan ulang untuk memastikan kegiatan organisasi berjalan sesuai aturan (Astuty, 2007).

Auditor internal menjalankan peran sebagai konsultan harus mampu memberikan saran untuk pencegahan terjadinya penyimpangan dan solusi jangka panjang bagi auditee. Auditor ikut berpartisipasi aktif membantu manajemen dalam mengambil tindakan perbaikan. Selain sebagai konsultan, peran baru auditor adalah sebagai katalisator. Katalisator bertugas dalam pembentukan nilai, moral dan budaya organisasi yang sifatnya jangka panjang (Astuty, 2007).

\subsection{Strategi Penerapan Paradigma Baru Peran Auditor Internal Pemerintah}

Tuntutan yang tinggi mengharuskan auditor internal memiliki strategi yang tepat dalam menghadapi berbagai perubahan-perubahan yang terjadi sehingga peran auditor dapat menjadi nyata (Rahayu dan Rahayu, 2016). Pickett (2010) yang selanjutnya diurai lebih rinci dalam Warta Pengawasan BPKP (2015) menyatakan bahwa dalam menerapkan paradigma baru, auditor internal harus dapat menambahkan fokus pekerjaannya menjadi:

1) Dari Hard Control menjadi Soft Control

Selama ini pengawas intern telah membina unit kerja lain dalam membangun 'hard control' yang baik, seperti penyusunan perencanaan kinerja, penyusunan sistem, penyusunan laporan keuangan, evaluasi kinerja, atau penugasan lain yang mendukung terbangunnya 'hard control' yang baik. Di masa mendatang, pengawas intern mulai menyentuh penugasan yang mendukung penerapan nilai-nilai dan etika organisasi serta integritas pegawai, terbangunnya kompetensi pegawai, atau terwujudnya pengawasan intern yang efektif.

Soft control merupakan jiwa dari pengendalian internal. Dimensi dari soft control berupa 1). Independensi dan Nilai Etika, 2) Komitmen Kompetensi, 3) Tone at the Top, 4). Budaya Kerja. Dimensi dari hard control yang diantaranya berupa : 1). Struktur Organisasi, 2). Standar Operasional Prosedur 3). Pengawasan (Husni, 2017).

2) Dari Control Evaluation menjadi Self Assessment Akhir-akhir ini aparat pengawas intern sudah mengamati kecukupan sistem pengendalian intern organisasi dalam mengantisipasi risiko. Pada umumnya kegiatan ini dilakukan melalui evaluasi atas kualitas sistem pengendalian intern yang dilakukan oleh tim pengawas intern, baik secara desk evaluation, maupun pengamatan, serta wawancara dengan pejabat yang bersangkutan.

Saat ini, pendekatan yang berkembang adalah melalui Control and Risk Self Assessment. Pendekatan ini dilakukan dengan metode yang berbeda, dimana pengawas intern berperan sebagai fasilitator bagi proses pembangunan secara mandiri terhadap sistem pengendalian dan pengelolaan risiko melalui sebuah diskusi kelompok atau teknik lain. Dengan pendekatan ini diharapkan identifikasi risiko, analisis risiko, penilaian risiko, respons risiko, serta aktivitas pengendalian yang harus dibangun disusun oleh unit kerja itu sendiri, yang dipandang paling memahami dan mengerti hal itu. Dimensi untuk control evaluation adalah aktivitas pengendalian. Sedangkan untuk self assessment adalah identifikasi risiko, analisis risiko, penilaian risiko, respons risiko dari pihak manajemen.

\section{3) Dari Control menjadi Risiko}

Jika sebuah organisasi hanya konsentrasi mengelola risiko tetapi tidak pernah menyempurnakan sistem pengendaliannya, yang terjadi adalah sebuah kesiasiaan. Jika suatu saat risiko itu muncul, organisasi tidak akan mampu mengantisipasinya dengan baik. Sebaliknya, jika organisasi hanya konsentrasi membangun sistem pengendaliannya, tanpa mengaitkan dengan risiko yang ada, maka sistem yang terbangun akan menjadi terlalu besar dan rumit serta 
tidak terarah. Hal ini sebuah pemborosan. Dengan pandangan ini, pengawas intern menyadari pentingnya mengelola risiko organisasi. Risiko menjadi fokus baru bagi pengawas intern di masa mendatang. Tanpa pengelolaan risiko yang optimal, tidak mungkin akan terwujud operasi organisasi yang efisien dan efektif.

Fungsi control lebih menekankan pada tugas memastikan dan mengevaluasi ketaatan terhadap prosedur dan peraturan. Kegiatan audit lebih bersifat compliance audit (Hery, 2017). Dimensi control adalah evaluasi terhadap kepatuhan (Hery, 2017); ketepatwaktuan dan orientasi terhadap hasil (Pickett, 2010). Dimensi Risiko adalah risiko audit. Risiko audit terdiri dari risiko bawaan, risiko pengendalian dan risiko deteksi (Jusuf, 2014). Selama ini, auditor menjadikan risiko bawaan dan risiko pengendalian sebagai dasar untuk penetapan risiko audit melalui risiko deteksi. Auditor internal mempunyai peran besar untuk mengurangi tingkat risiko bawaan dan risiko pengendalian.

\section{4) Dari Detective menjadi Preventive}

Selama ini tugas pengawas intern identik dengan pemeriksaan atau audit. Penugasan pengawas intern selama ini didominasi dengan kegiatan-kegiatan yang bersifat mendeteksi penyimpangan. Perubahan paradigma saat ini membawa peran pengawas intern yang lebih luas dan strategis pada organisasi. Pengawas intern tidak sekedar 'watch dog', namun sebagai sebagai konsultan dan penjamin mutu. Dengan peran dan fungsi ini, maka penugasan yang dilakukan lebih banyak yang bersifat preventif atau pencegahan.

Kegiatan detektif dan preventif ini termasuk bagian dari aktivitas pengendalian. Preventif fokus kepada pencegahan terjadinya kesalahan dan hal-hal yang tidak lazim. Detektif fokus pada menemukan kesalahan dan hal-hal yang tidak lazim untuk kemudian di koreksi atau dilakukan tindakan perbaikan (Tuanakotta, 2014). Kegiatan Detektif dan preventif merupakan bagian dari aktivitas pengendalian. Beberapa kegiatan detektif dan preventif terkadang dilakukan bersamaan.

\section{5) Dari Audit Knowledge menjadi Bussiness Knowledge}

Perubahan dimensi ini membawa konsekuensi pada diri pengawas intern. Konsekuensi utamanya adalah perubahan kompetensi yang harus dimilikinya, termasuk pengetahuannya. Jika selama ini pengawas auditor harus dibekali dengan pengetahuan mengenai pengawasan (audit knowledge), di masa mendatang pengetahuan tentang core bussiness organisasi tidak kalah pentingnya. Dengan demikian perubahan dimensi pengawas intern telah membawa perubahan fokus dari audit knowledge menjadi bussiness knowledge.

Audit knowledge dibutuhkan mulai dari proses perencanaan sampai dengan pelaporan hasil audit, yang ditentukan oleh kompetensi auditor. Dimensi untuk audit knowledge adalah kompetensi auditor internal. Sedangkan business knowledge merupakan pemahaman auditor terkait usaha yang dijalankan oleh auditee. Pemahaman yang menyeluruh atas bisnis dan industri serta pengetahuan tentang operasi diperlukan untuk pertimbangan auditor terkait penentuan risiko dan rencana audit (Hery, 2017). Dimensi yang dapat digunakan adalah pemahaman terhadap usaha klien.

\section{6) Dari Operational Audit menjadi Strategy Audit}

Fokus pekerjaan pengawas intern pada masa lalu lebih didominasi dengan pemeriksaan pada level bawah organisasi, yaitu melalui audit ketaatan dan audit operasional. Perubahan dimensi pengawas intern ini telah menambah fokus dengan melakukan evaluasi terhadap produk-produk level atas organisasi. Pengawas intern di masa mendatang akan lebih terlibat dalam melakukan evaluasi terhadap strategi organisasi dalam mencapai tujuan. Jenis penugasan seperti policy evaluation atau strategy audit akan menjadi fokus baru di masa mendatang.

Audit operasional adalah prosedur yang sistematis untuk mengevaluasi efisiensi dan efektivitas kegiatan suatu organisasi untuk mencapai tujuan organisasi tersebut, dan keekonomisan operasi organisasi yang berada dalam pengendalian manajemen serta melaporkan kepada orang-orang yang tepat atas hasilhasil evaluasi tersebut beserta rekomendasi untuk perbaikan (Bayangkara, 2008). Hasil akhir dari suatu audit operasional biasanya berupa rekomendasi kepada manajemen untuk perbaikan operasi (Tandiontong, 2016). Dimensi dari audit operasional adalah Review dan Pengujian Pengendalian Manajemen (Bhayangkara, 2008) dan Evaluasi Efisiensi dan Efektivitas (Tandiontong, 2016).

Audit Strategi merupakan fokus tambahan bagi auditor internal saat ini. Audit strategi terkait dengan reviu yang dilakukan auditor internal terhadap rencana dan strategi organisasi untuk mengidentifikasi kelemahan dan penyimpangan serta kemungkinan pengembangan keberhasilan organisasi. Proses kerja yang dilakukan dapat berupa reviu kondisi organisasi saat ini, melakukan interviu dengan tim manajemen, analisis terhadap logika usaha dan hasil dari evaluasi terhadap rencana dan strategi harus diekspose secara internal (Strategic Management Institute). Tahapan perkerjaan ini menjadi dimensi yang digunakan untuk audit strategi.

\section{7) Dari Independence menjadi Value}

Independensi sering kali menjadi fokus dalam pelaksanaan tugas pengawas intern selama ini. Pada dimensi baru, hal ini tidak terlalu menjadi fokus perhatian lagi. Hal ini terkait dengan perubahan tujuan keberadaan pengawas intern yang berkembang menjadi pendorong terciptanya value bagi organisasi. Fokus diskusi berubah dari masalah independensi menjadi bagaimana caranya agar pengawas intern dapat menciptakan value atau nilai bagi organisasi. 
Dalam menjalankan peran dengan menggunakan paradigma baru, auditor internal harus berusaha menerapkan strategi-strategi tersebut.

(Sawyer, Dittenhofer, \& Scheiner, 2010) menyatakan Independensi dalam audit:

1. Bebas dari intervensi manajerial

2. Bebas dari segala intervensi atas prosedur audit.

3. Bebas dari segala persyaratan untuk penugasan audit selain yang memang disyaratkan untuk sebuah proses audit.

Tingkat independensi auditor eksternal sering dianggap berbeda dengan auditor internal. Independensi Auditor internal sering diragukan karena merupakan bagian dari institusi dan bertanggung jawab salah satunya terhadap pimpinan. Walaupun masih bisa independen terhadap unit kerja lainnya dalam institusi. Dimensi untuk independensi berupa independen dalam fakta dan independen dalam penampilan.

Perubahan peran auditor internal sebagai konsultan dan katalisator, menekankan auditor harus mampu memberikan nilai tambah (value added). (Mulyadi, 2005) menjelaskan bahwa terdapat tiga kondisi suatu aktivitas dapat dinyatakan menambah nilai yaitu:

1. Aktivitas yang mampu menghasilkan perubahan suatu keadaan

2. Perubahan sifat tersebut tidak dapat dicapai oleh aktivitas sebelumnya,

3. Aktivitas tersebut memungkinkan aktivitas lain dapat dilaksanakan.

Dimensi untuk value added antara lain adalah pemahaman terhadap risiko yang dapat diwujudkan melalui pemahaman terhadap bisnis klien, penyelarasan strategi audit dengan kebutuhan auditee dan penempatan sumber daya yang tepat dalam proses audit serta proses audit internal yang sistematis dan terstruktur seperti kegiatan bisnis (Ernst \& Young, 2012).

\subsection{Faktor Pendukung Transformasi Perubahan Peran Auditor}

Auditor internal yang menjalankan peran sebagai konsultan dan katalis akan sangat ditunggu oleh unit kerja (Wiwoho, 2018). Penerapan peran baru auditor internal akan terhambat diantaranya adalah jika auditor tidak memiliki kompetensi, dan tidak adanya komitmen pimpinan, serta kesadaran auditee (Rahayu dan Rahayu, 2016).

Beberapa faktor pendukung optimalnya perubahan peran auditor antara lain kompetensi SDM (yang ditentukan oleh latar belakang pendidikan, pelatihan dan pengalaman). Dukungan sarana dan prasarana termasuk anggaran juga menjadi faktor penting dalam kelancaran aktivitas auditor internal dalam menjalankan perannya. Hal ini dapat menjadi salah satu indikator komitmen pimpinan. Komitmen pimpinan juga terkait dengan kemauan dan kesadaran untuk menerapkan unsur-unsur pengendalian internal di lingkungan kerjanya. Bukan hanya pada tingkat pimpinan tertinggi namun juga sampai dengan pimpinan pada lini terendah. Komitmen pimpinan akan mendorong terciptanya komitmen seluruh unsur dalam organisasi, dan akhirnya akan tercipta kesadaran auditee.

\section{Kesimpulan}

Pengawasan terhadap penerapan sistem pengendalian internal pemerintah menjadi salah satu tugas dari Aparatur Pengawasan Internal Pemerintah (APIP). Indonesia menghadapi permasalahan APIP dari sisi kuantitas maupun kualitas APIP. Pada tahun 2014, Auditor internal yang tersebar di pemerintah pusat, daerah, BUMN dan organisasi pemerintah lainnya berjumlah 12.755 atau $(27,94 \%)$ dari total kebutuhan nasional 46.560 sehingga terjadi kekurangan 33.805 auditor. Pemerintah menargetkan pada tahun 2019 diharapkan berjumlah 20.255 auditor atau 43,50\% dari kebutuhan nasional.

Saat ini, auditor internal menghadapi perubahan paradigma dalam menjalankan perannya. Paradigma baru mengikuti tuntutan perkembangan organisasi menuju tingkat yang lebih tinggi. Internal auditor tidak dapat lagi hanya berperan sebagai watchdog, namun harus dapat berperan sebagai konsultan dan katalisator yang tugasnya seperti mitra bisnis. Penulis mengungkap tujuh tambahan fokus pekerjaan auditor internal yang dapat menjadi strategi dalam penerapan paradigma baru yaitu dari (1) dari hard control menjadi soft control; (2) dari control evaluation menjadi self assessment; (3) dari control menjadi risk; (4) dari detektif menjadi preventif; (5) dari audit knowledge menjadi bussiness knowledge; (6) dari operational audit menjadi strategy audit dan (7) dari independen menjadi value. Peran baru auditor internal akan terhambat diantaranya adalah jika auditor tidak memiliki kompetensi, dan tidak adanya komitmen pimpinan, serta kesadaran auditee.

\section{Daftar Pustaka}

Anto, A., Sutaryo, \& Payamta. (2016). Determinan Efektivitas Audit Internal Pemerintah di Indonesia. Paper presented at the Seminar Nasional Akuntansi XIX, Lampung.

Astuty. (2007). Peran Internal Auditor sebagai Watchdog, Consultant dan Catalisy. Jurnal Riset Akuntansi dan Bisnis, 7(1 (Maret).

Bastian, I. (2006). Sistem Akuntansi Sektor Publik.

Jakarta.: Penerbit Salemba Empat.

Bayangkara, I. (2008). Audit Manajemen: Prosedur dan Implementasi. Jakarta: Salemba Empat. 
BPK. (2017). Ikhtisar Hasil Pemeriksaan Semester 1

Tahun 2017. Jakarta: Retrieved from http://www.bpk.go.id/ihps/2017.

Diamond, J. I. M. F. F. A. D. (2002). Performance Budgeting-- Is Accrual Accounting Required? [Washington, D.C.]: International Monetary Fund.

Ernst, \& Young (Producer). (2012, 26 Maret 2017). The Future of Internal Audit is Now-Incerasing Relevance by Turning Risk Into Result. Retrieved from https:// www. eycom.ch/en/Publications/ c20120718-The-future-of-internal-audit-is-now

Hery, S. E., M.Si., CRP., RSA., CFRM. (2017).

Auditing dan Asurans; Pemeriksaan Akuntansi berbasis Standar Audit Internasional, Integrated and Comprehensive Edition. Jakarta: Grasindo.

Hidayat, M. A. (2011). Peranan Audit Intern sebagai Strategic Business Partner di PT. Pertani (Persero) Wilayah Sumatera Bagian Selatan. Jurnal Ekonomi dan Informasi Akuntansi (JENIUS), 1(1 (Januari 2011).

Husni, M. (2017). Pengaruh Soft Control Dan Hard Control Terhadap Hasil Temuan Audit Internal Di Perusahaan Daerah Air Minum Se-Provinsi Banten. Strata 2, Universitas Esa Unggul, Jakarta. Retrieved from digilib.esaunggul.ac.id/ UEU-Master201403024/8649

InspektoratProvinsiJawaTengah (Producer). (2016). Transformasi Fungsi Audit Intern Pemerintah: Meningkatkan Kapabilitas APIP. Retrieved from http://inspektorat.jatengprov.go.id/2015/ pocontent/poupload/4.\%20\%20DEPUTI\%20PKD\%20-\%20Da dadng\%20K..pdf

Jones, R., \& Pendlebury, M. (2010). Public Sector Accounting (Sixth ed.). London: Pearson Education Ltd.

Jusuf, A. H. (2014). Auditing (Pengauditan Berbasis ISA). Yogyakarta: STIE YKPN.

Mulyadi. (2005). Akuntansi Manajemen. Jakarta: Salemba 4.

Pickett, K. S. (2010). The Internal Auditing Handbook: John Wiley \& Sons.

Pramono, A. J. (2016). Analisis Faktor-Faktor yang mempengaruhi Transformasi Kapabilitas
Organisasi dan Peran Badan Pemeriksa Keuangan RI. Jurnal Tata Kelola dan Akuntabilitas Keuangan Negara, 2(2 (Desember 2016).

Rahayu, \& Rahayu, S. (2016). The Role of Internal Auditor Government to Realize the Clean Local Government. Paper presented at the Malaysia Indonesia International Conference of Economics, Management and Accounting (MIICEMA) 2016, Jambi

Sawyer, L. B., Dittenhofer, M. A., \& Scheiner, J. H. (2010). Audit Internal Sawyer. Jakarta: Salemba Empat.

Tandiontong, M. (2016). Kualitas Audit dan pengukurannya. Bandung: Alfabeta.

Tuanakotta, T. M. (2014). Audit Berbasis ISA. Jakarta.: Salemba Empat

Wiwoho, J. (2018). Membangun Inspektorat Jenderal dengan Paradigma Baru. Majalah Pengawasan, INFESTERA, 1. 